\title{
The analysis of innovation and develop- ment of higher vocational colleges
}

\author{
Zheng Zhong \\ Chongqing Business Vocational College, Chongqing, 400036
}

\begin{abstract}
In a competitive market, country begins to pay more attention to higher vocational colleges, but how to make higher vocational college more powerful and stronger? The preferred way is recreating the school-running mode. We should try the innovative road of from resource, business concept, management and model of teaching.
\end{abstract}

Keywords: higher vocational college, school-running mode, innovation

As we all know, through the initial period of suspect, hesitation and puzzle, higher vocational college is in a relatively stable developing period gradually. As the strategic focus for the current and future period of education work, it should take effective measures to promote rapid, continued and healthy development for vocational college. This is the good news for higher vocational college. But we should also know, there is serious restriction for their development, such as develop respectively for their own, repeated majors, waste resources, less prominent specialization, weak flexibility, inferior scale effect and not service market-oriented economy close. Therefore, we should accelerate reformational pace, innovating school-running mode, to be stronger, powerful and characteristic.

\section{Resource innovation}

Nowadays, there are many types of higher vocational college, but basically they are independent operation, scattered resources, obvious class-type, and less close to enterprise, weak professional skills of students and less demanded by enterprise. Vocational education should service local economy on one hand; on the other hand, it should compete with other cities. So it must convert people's perception, remake traditional-mode, and create a work-learning path and a schoolenterprise path. As the important strategic resource, vocational education and training should be integrated. From the development side, higher vocational college should face to the demand of enterprise, perfecting the service function for vocational education, vocational training, and professional skill appraisal and technical support. For this purpose, we could integrate resource of vocational colleges, make a profession perfect, do a profession best, and make the higher vocational college characteristic, to make higher vocational college more systematized and normalized. Thus, it is necessary to build modern typical-standard basement for working and learning, the training basement, open-running school mode facing market, enterprise and colleges. This school management can not only complete professional knowledge teaching with vocational training direction, but also can strength practice, reserve development space for students' career, and 
maximize the use of resource for colleges and enterprises.

\section{Operation innovation}

Since college enrollment has been increasing, all vocational colleges run business difficultly, without catching its breath. In fact, this is because our business is too simple and too rigid. For the sustainable development of institutions, larger grade on the scale, public higher vocational colleges should try to integrate, reconstruct, and collectivize vocational colleges, run chain school, establishing the Vocational Education Group, expanding the size of school, and exploring the running-school mode with the public sector-led, property rights, coexistence of diverse forms of ownership (to attract private capital and foreign capital). Vocational education should be diversified. It should encourage the community, the collective economic organizations and individuals with the voluntary principle donate capital to run schools for society, such as people help to run public school, government help to run private school, collect capital and enterprise cooperation in running schools and other the main pattern of school. It should apply for market-oriented operation, with competition mechanism and fair competition evolution, to maximize resources with best social benefits and economic benefits, introducing the idea of industrialization, productivity combined with teaching and research, to have a developing road of teaching, industry and research. It can be achieved by unified award, different campus and different profession management, a school with two campuses, to invigorate the business and market. This can be complementary advantages, solving funding, hardware, teachers and other issues.

\section{Management innovation}

In order to improve students' practical innovative ability and employability, higher vocational college must insist on user demand-oriented, innovating teaching management mode. The unique basis for vocational education is to satisfy market demands. Under the condition of market economy, the fundamental breakthrough for developing vocational education is to import the concept of user, which means we should convert traditional structure between enterprise and academy into ternary structure among enterprise, user and academy. Academy is not only the important part of enterprise structure, but also the creator for enterprise strategic resource. In a user-driven competition, it is necessary for vocational education to hold user to win the market, breaking through on the innovation teaching management mode to get the development.

First, vocational education is focusing on optimizing human resource for enterprise, preparing high-quality talent for enterprise and society. We should intensify ordering cultivation and always grasp the needs for enterprise, to cultivate golden collar, which means practical skill talents. This target means we should set up profession and compile practical teaching material. Second, it is necessary to seize the regular law for cultivating technical talents, developing the new pattern for vocational education. Development is decided by thoughts and achievement is decided by field of vision. It is the basic demand for vocational education and the basic regular law for cultivating technical skilled talents, which is the combination of working and learning, knowledge learning and technical training, class education and job training, professional quality and professional ability, the campus base and enterprise site, academy running and enterprise support. Third, higher vocational college should reform in the in- 
ner management mechanism of academy, building flexible, effective and clear responsibilities' operation mechanism. The core of management mechanism reform is principal responsibility, teacher employment system and contract system for teaching management personnel. Teacher appointment system should be established, to develop the competitive and incentive mechanism, which means appoint people with less experience for high position and people with more experience for low position, post can be promoted or demoted, the treatment can be high or low, and personnel can flexible. The distribution principle, including salary decided by post, wage decided by work, and best reward decided by high quality work, can fully mobilize the staff's enthusiasm of the work.

\section{The teaching model innovation}

Over the years, higher vocational college's teaching mode is either high school exam-type, either theoretical model of university without their own practical style. Therefore, under the guidance of education experts, some colleges try to task-driven curriculum reform, innovating the teaching plan, achieved good results. The purpose of task-driven is to focus on the inner need for students' lifelong development, focus on the students' personality for their all-round development, combining the campus study, outside school life, career needs and interest closely. In the teaching, combine the task-driven and the curriculum learning's knowledge, skill and ability closely, combine the curriculum learning and dealing with all the complicated social life relationship together, and combine all the subjects' knowledge, the subject knowledge and life, the resource integration and learning style integration. Through subjects' integration, students can deal with relative information from multiple perspectives, to understand knowledge and solve problem more comprehensively and objectively. Through task-driven curriculum, it makes academy learning and social work more coordinating for students to get learning ability for study and work, get knowledge and skilled professional ability, get basic and key live ability, and get basic ability for social living. When the labor organization changes or when the career change, this ability can still exist and new knowledge and skills can be grasped. It is thus clear that task-driven with various teaching methods can intensify practical ability and professional technical ability with people-oriented. Students' individual sustainable and harmonious development can be achieved, if we respect learner's need, focus on all-round quality cultivation, and pay attention to the various services for learners.

By the construction of appreciationbased moral education, life moral education, and professional activity-oriented moral education, we can find effective and multiple working methods for moral education, which is suitable for vocational students' individual characteristics and meets the requirement of college's moral education in new era from multiple perspectives, various levels, different systems and scientific methods. From guidance and cultivation mode to moral education appraisal system, from building specific belief to perception in life practice, constructing multiple moral educations can reinforce work in moral education and show the dominant position of moral education. Through a large number of extracurricular activities and professional training activities for students, students learn to study, think and understand in these activities and learn to appreciate, gratitude and love life to make moral education harmonious based on direct, dynamic and experience qualities. By creative moral education, college could culti- 
vate less dangerous students and inferior students, and more qualified students and excellent students. These good students in college can be good employees in company, good citizen in society with devoted and honest professional morality education.

The teaching of vocational education has their special requirements. Their relevant theory not only has certain of particularity, but only has systematicness and flexibility. With the development of vocational education, the requirement for professional teacher is getting higher and higher. For this reason, higher vocational college must build a high quality teacher team, who is determined to be creative and good at innovation. First, we must strengthen teacher's professional ethics and put one-vote negation system of teacher morality into effect. Second, reasonable structure of teaching staff should be established. Theoretical course teacher and specialized course teacher cannot be distinguished exactly and middle-aged teacher cannot too short. College should encourage teacher, especially cultural course teacher, to become expert in one field while possessing all-round knowledge and ability, and to be "double type" teacher. Therefore, college could encourage young and middle-aged teacher to get out of school and take part in practical work in the enterprise and relevant industry, to improve their comprehensive practical ability. College could also import professional and technical talent with strong practical ability from enterprise directly or relevant industry. By pre-job training, these talents can be college's backbone of the teaching. Or college could employ high quality parttime double teacher. At the meantime, with new technology and new workmanship emerging endless in society, policy should be introduced to encourage teacher to enhance self-study steadily and update their own knowledge constantly.
Third, college should increase research efforts, promote teaching by research, and encourage teacher to take part in research actively, to make learning combined with practice and research truly.

In conclusion, innovation is soul and opportunity. Vocational education can seek develop in fierce competition only with innovate school-running mode, trying their best in economic society transformation, safe displacement of rural labor force, improving the overall quality of workers and the construction of harmonious society.

\section{References}

[1] Lu Wuxia, “ The Core elements and construction of connotative development in higher vocational college [J]. Journal of education and career, 2012 (20): 31-33

[2] Zhang Lijin, " The strategy of connotative development in higher vocational college: resources integration ," Journal of higher education research, pp. 82-87, 2007.

[3] Dong Gang, Yang Lilian, “ The elements analysis and approaches research of connotative development in higher vocational college," Journal of vocational education BBS, pp. 8-10, 2010.

[4] Lin Jun, " The analysis of Innovation and development in higher vocational colleges in underdeveloped areas," Journal of education and profession, pp. 8-10, 2012.

[5] Fu Chunsheng, " The research of Innovative mode of talent training in higher vocational education ," Journal of guangxi social science, pp. 161-163, 2010. 